\title{
A Mechanism of Urban Formation in Developing Asia: A Case of the Pearl River Delta Region, China
}

\author{
Jun ONODERA \\ Institute of Geography, Graduate School of Sciences, Tohoku University, \\ Sendai 980-8578, Japan
}

\begin{abstract}
This paper aims at considering a mechanism of urban formation in Asia, focusing on the growth of small towns under the economic reform since the 1980s in the Pearl River Delta region, southern China. A discussion on the extended pattern of urbanization in Asia and some models of China's economic development are reviewed as a frame of reference. The extended urban formation in the Pearl River Delta region is considered to be the incorporating process of the region into the New International Division of Labour. Some Hong Kong-based enterprises have started to locate large-scale factories to the region, while they have left headquarters functions in Hong Kong. Those factories have employed a lot of workers from a segmented regional labour market of immigrants. Local communities in rural areas have accumulated land profits from the compensation of land expropriation and rent of collectiveowned land to promote land development in their domains. While foreign enterprises aggressively invest in the region in pursuit of preferable location for their production, local communities in rural area as well as local government competitively develop their land and construct facilities on it in order to invite more foreign investment. As a result, these movements have brought about rapid changes in the landscape of the region.
\end{abstract}

Key words: urban formation, international division of labour, capital accumulation, the Pearl River Delta region, China

\section{Review on Extended Pattern of Urbanization}

This paper aims at considering a mechanism of urban formation in Asia, focusing on the growth of small towns under the economic reform since the 1980s in the Pearl River Delta (PRD) region, Guangdong Province, China. Urban formation, the physical formation of the urban landscape rather than changes in social lifestyle or political systems, is one of the aspects of urbanization. Population growth high population density, and the increase in the number of cities and towns, are important elements in urban formation. Nevertheless, this paper also pays special attention to the increase in urban land use, which includes the expansion of built-up areas and construction of infrastructure, public facilities, and other buildings. In order to understand how urban landscape has been formed, we must investigate the process of capital accumulation that underlies the physi- cal urban formation in a region.

The emergence of an extended pattern of urbanization in Asia has recently drawn the attention of a number of geographers. McGee $(1989,1991)$ insisted that the Western paradigm of urban transition was clearly not transferable to the urbanization process in developing countries. He focused instead on a unique urbanization pattern in Asia, named 'desakota' (a coined Indonesian term meaning village and town). The main features of desakota are as follows: (1) a large population, small-holder cultivation of rice, accessible transportation, (2) an increase in non-agricultural activities, (3) fluidity and mobility of the population, (4) an intense mixture of land use, (5) the increased participation of females in non-agricultural labour, and (6) 'invisible' or 'grey' zones from the viewpoint of the state authorities.

This kind of conception does not fit well with the conventional idea of urbanization. Still, it is not necessarily a process occurring in isolation from existing cities. It is more appropriate to 
regard this as an extending process of marketoriented activities in the context of a rural society. Ginsburg $(1990,1991)$ named the same phenomenon 'extended metropolitan regions'. McGee and Yeung (1993) added to the following features to those listed above: (7) an increasing proportion of their countries' population and economic growth, (8) a large proportion of infrastructure investment, (9) a declining birthrate, and (10) growing household income.

A desakota area is acknowledged in the PRD region of southern China (Johnson 1992, 1995; Zhou 1996). Small and medium-sized cities and nearby townships have developed economically in a zone along the arterial highways between Hong Kong, Shenzhen, Dongguan and Guangzhou (Zheng and $\mathrm{Wu}$ 1993; Chan 1995). Settlements have sprung up along the trunk roads between the urban units in the region on land converted from farmland. Many township factories mushroomed along the roadside (Woo 1994).

The development of small towns (xiao chengzhen) in the southern Jiangsu Province has also been studied (Fei 1984; Fei et al. 1986; $\mathrm{Ma}$ and Fan 1994). The functions of small towns in rural development have much in common with those of desakota. Fei (1984) placed much value on the autonomic process of rural development that originates from local capital and resources and emphasized the need to promote the development of small towns in policy. Wu et al. (1987) also thought highly of small towns as the providers of 'basic needs' for their neighbours. There was a general agreement that a decentralized urban system was an effective method for the economic development of the vast rural areas in China ( $\mathrm{Ma}$ and $\mathrm{Hu}$ 1993; Leung and Chai 1985).

On the contrary, there are some who are sceptical about the development of small towns in China. The small towns did not have enough autonomy to solve many administrative, financial, technological, personnel, and material problems (Tan 1989). The capital costs of both developing industry in the thousands of small settlements, and providing them with essential urban-style infrastructure, were regarded as completely insupportable. Urbanization, which constrained the large and medium-sized cities, would also constrain capital accumulation (Kirkby 1988: 233). Marton (1994) doubted the validity of the rural development model in the PRD region which was mostly dependent on outside influences in comparison with the autonomous model in the Yangtze River Delta region of eastern China.

However, there has been an active discussion on the extended pattern of urbanization. 'Desakota' is translated into Chinese with terms like 'chengxiang ronghequ' (urban-rural fusion area) (Zheng and $\mathrm{Wu}$ 1993: 15) and bears a close resemblance to the concept of 'xiangcun chengzhenhua' (rural urbanization) (Zhou 1993: 13) or 'chengxiang yitihua' (urban-rural integration) (Yan et al. 1994: 142). These terms are often stated in the historical context of China. Although the extermination of urban-rural differences was one of the principal targets for the economic development of socialist China, the differences were fixed or fostered under the planned economy. The flows of all sorts of production factors, especially labour force, were restricted between the separated economic systems of urban and rural areas (Shi 1998). 'Chengxiang yitihua' is explained in the context of their expectation of the process of breaking the fence between two areas and modernizing them together in terms of residence, life, facilities, environment, management, and so forth (Xue et al. 1998; Wei 1999). 'Chengxiang ronghequ' is interpreted to be a spatial consequence of 'Chengxiang yitihua', while 'xiangcun chengzhenhua', including the changes of employment structure and landscape in rural areas, is regarded as a phase of 'Chengxiang yitihua' (Xu 1998).

Furthermore, the notion of an area of urban agglomeration (chengshiqun) that contains several large cities and a great number of small cities and towns has also been developed. This concept has been regarded as a stage of urban growth toward the formation of a megalopolis (chengshidai) (Zhou 1991; Yao 1991; Yao et al. 1992; Zheng 1989; Zheng and Wu 1993). Yet, room remains for further discussion on the division of labour among cities and towns within the agglomeration. Especially, capital and labour flows among them should be examined in detail. 
A considerable number of studies have been conducted on urbanization in the PRD region. A series of studies conducted by Sit (1991, 1993, 1995), Sit and Yang (1997) and Xue and Yang (1997) focused on a type of urbanization that was caused by foreign direct investment through Hong Kong, which was named 'exo-urbanization'. In fact, the remarkable economic development of the PRD region under economic reform is chiefly attributed to its close links with Hong Kong (Xu et al. 1995). For example, Maruya (1992) clarified the outprocessing relations that exist between enterprises in Hong Kong and factories in the PRD region. He represented their quantitative relations by data on re-export through Hong Kong. Soulard (1993) devoted many pages to an examination of the intensification, rationalization, technical change and transplantation of transnational corporations (TNCs) in Hong Kong and the PRD region. Lin (1997) explained the rapid urbanization in terms of regional economic development and pointed out internal economic forces in the region.

The spatial pattern of urbanization in the region is, of course, an important subject among geographers (Xu et al. 1988; Lo 1989). Pannell and Veeck (1989), Xu and $\mathrm{Li} \mathrm{(1990)} \mathrm{and}$ Druijven (1993) examined the hierarchy of cities in the PRD region and took notice of growing small towns and cities, whereas Zheng (1989), Xu (1988) and $\mathrm{Xu}$ and $\mathrm{Hu}$ (1988) investigated the links or interactions between cities including Hong Kong and Macao. The definition of urbanization was re-examined by Guldin (1992) and Johnson (1992) in the context of China and the PRD region. Labour migration was regarded as another aspect of urbanization in the PRD region (Chan 1996). The origin, destination, number and attributes of the migrating population were analysed with limited population data (Li 1989; Li and Siu 1994; Oshima 1996).

Although the existence of a desakota has been acknowledged and the role of the small towns in regional development has been discussed, few attempts have so far been made to study the mechanism of the formation of small towns or a desakota area. As stated above, the purpose of this paper is to consider the mechanism of the unique urban formation in the PRD region. It is impossible to achieve this purpose simply by describing the spatial pattern of urbanization. Because the formation of an urban landscape requires a large amount of capital, the mechanism that underlies urban formation can be effectively clarified through an examination of capital flow: i.e., how capital is generated, how capital is transferred, and how it is finally accumulated. In addition, it is expected that the examination of the mechanism of urban formation in southern China will contribute to the discussion of the urbanization process in Asia which is accompanied by rapid regional economic development.

\section{Endogenous and Exogenous Economic Development}

Some studies have focused on 'endogenous development' as a model of China's economic development in the 1980s, which placed emphasis on the utilization of local resources, labour, and capital. Endogenous development is defined as 'the adaptation of residents themselves to regional natural ecosystems and the creation of new systems of production and distribution or new ways of living by their innovative ideas on the basis of traditional society and spirituality' (Tsurumi and Kawata 1989). In economic terms, the labour productivity of the agricultural sector rose first after the introduction of the production responsibility system in rural areas. Capital accumulated and surplus labour force disclosed in the agricultural sector were then invested in 'township enterprises' (xiangzhen qiye) within a local community.

The development pattern of township and village industry in China was conspicuous among the industrialization patterns in Third World countries (Yamauchi 1988). Because modern industry in the Third World cities was capital-intensive or did not grow sufficiently, it could not absorb the influx of rural workers. As a result, the lower class population increased sharply and formed informal sectors, which led to the problem of overurbanization. In China, on the other hand, as the population movement from rural to urban areas was restricted to a considerable degree, a new type of industriali- 
zation, whereby township and village industries absorb surplus agricultural labour force locally, took place. Many farmers abandon farming and work in local factories so that they do not readily leave their countryside to go to cities. This process can be described by a common Chinese saying: 'li tu bu li xiang' (leaving the land, but not the countryside).

Chinese farming villages basically specialized in grain production during the period of the people's communes. However, along with the deepening economic reform, the rural economic structure has changed since the end of 1970s. The core of this change was the development of township and village industry. That is not to say, however, that rural industry suddenly appeared at that time. 'Wuxiao gongye' (five small industries), consisting of small-scale steel plants, machine factories, fertiliser factories, coal mines, and cement plants, were developed to support agriculture during the period of the 'Great Leap Forward'. 'Shedui qiye' (communeand brigade-run enterprises) were set up under the people's commune system. Although their chief purpose was still to support agriculture, they were certainly the prototypes of township and village enterprises.

Fei et al. (1986) advocated a rural economic development model based on the actual conditions observed in southern Jiangsu Province. This is commonly known as the 'Sunan model'. Various other models have been reported in addition to the Sunan model (Chen 1988), but they are regarded as individual models which reflect the different initial conditions in each part of the country. In the Sunan model, rural industry, which was set up on the basis of peasant investment, absorbs surplus labour in agriculture to invest its own profits in the modernization of agriculture. This offered a means of indigenous modernization different from that of the West in which they realized rural modernization by incorporating rural economy into urban economy (Uno 1989).

The driving force of developing rural industry was the movement towards capital accumulation by the peasants, most of whom 'think much of industry and think little of agriculture'. Through his research on rural socio-economic structure based on frequent fieldwork, Ishida (1988) discovered a collective principle at work in rural industry. The profits of rural industry were not fully invested in expanded reproduction. Instead, as well as being used to increase individual incomes, a considerable part was appropriated to finance education and welfare in the village. Fettered by this collective principle, rural industry found it difficult to develop further. Ishida also pointed out that, due to too much emphasis upon rural industry, agricultural output was declining, and he argued for the necessity of increasing financial input into the agricultural sector. Oshima (1987) maintained that the purpose of rural industry should be to build up the processing of agricultural produce and the supply of agriculture-related production goods (Onodera 1991).

These researchers tried to explain the development of rural industry from the indigenous standpoint of the rural community. As long as the rural community is considered to be a closed area economically, the collective principle can be understood to regulate rural industry. However, it is unrealistic to ignore the influences from outside the rural community under the market-oriented economy of recent years. Some rural industries had already been assisted by urban industries, large-scale state and collective enterprises in cities, by way of funds, technical knowledge, managerial skills and marketing contacts. They sometimes got incorporated into the subcontract system of urban industries (Onodera 1991).

Some parts of China's coastal area, such as the PRD region, southern Fujian Province including Xiamen, and recently Shanghai, have already gone beyond endogenous development models and are now affected by 'exogenous' factors through foreign trade and investment. The term 'extrovert development' is used to refer to the situation in which domestic economic players utilize exogenous factors with relative independence (Uno and Zhu 1991; Uno and Tsurumi 1994). The development model emphasizes the independence of domestic economic players and tends to play down the role of foreign capital as being only a means of introducing technology and funds. In the recent economic development in coastal areas 
of China, however, it certainly appears that the dynamism of development is exogenous.

It may be worth mentioning the concept of 'customary economy' here. 'Customary economy' is usually based on a rural community whose economic goal is the securing of a minimum subsistence level for or the improvement of the community welfare for all members. The members help one another, abiding by the rule of community which regulates their duties and privileges. It is probable that a small-scale factory is engaged in unprofitable production for the community members, and that family employment reduces the need for social welfare investment and provides cheaper labour force to the community (Armstrong and McGee 1985).

While the market economy, or capitalist mode of production, has been infiltrating into every inch of the rural area forming a new urban system for extracting surplus even from the rural area, the customary economy, or noncapitalist mode of production, of the traditional rural community has been maintained. Furthermore, the customary economy is articulated with and restructured by the spreading market economy so that it forms a unique economic system in each region (Forbes 1984; Forbes and Thrift 1987; Ishikawa 1990). The different spatial and social structures in various regions of the Third World can be explained as modifications of the simple world-wide capital accumulation model (Gilbert and Gugler 1992: 43), which are based upon the articulation of the dominant market economy and the subordinate customary economy. Not taking the fixed dualistic view of endogenous and exogenous economic development, or of customary and market economy, allows us to explore the mode of their articulation in a region.

\section{Capital Accumulation in the Pearl River Delta Region}

It is universally admitted that the investment of TNCs has strong influence on the economic development of a region. When headquarters (H.Q.) of manufacturing TNCs locate themselves in cities, their factories engaged in production do not necessarily do so. Particularly when TNCs are planning mass production, they prefer to establish factories in rural areas. Large factories need to occupy large areas of cheap land for their sites and to employ a large number of unskilled workers from the rural labour market at low wages. TNCs would absorb surplus value through a spatial division of labour between H.Q. in urban areas and factories in industrializing areas among rural areas. Such spatial division of labour has been formed between Hong Kong and the PRD region in recent years. A number of H.Q. of TNCs have agglomerated in Hong Kong, while their branch plants have been located in many parts of the PRD region (Onodera 1998).

The factories of TNCs for mass production need abundant unskilled labour force; diligent, handy, obedient, non-unionized, and cheap workers are very popular with factory managers. Those who most readily meet these conditions are young females. In the beginning, factories tend to employ local peasants and promote a region-wide shift in employment from agriculture to manufacturing. As factories increase employment and the locally available workforce is insufficient to meet their needs, the wages for workers tend to increase. Entering upon this phase, factories begin to look for cheaper labour force in other regions. They have two alternatives: the relocation of their factories to regions or countries that have more favourable labour markets, or the recruitment of workers from those regions without the relocation of factories. The first alternative requires a large amount of capital in order to set up new factories. They, therefore, try to postpone relocation in favour of the second alternative. If they can manage to recruit migrant workers and secure a new labour supply, the corporations are able to continue to operate their plants at the same location at relatively low cost. After a regional labour market is formed by the continual influx of migrant workers, it is possible for factories to enlarge their production scale (Onodera and Oshima 1996). A part of surplus value is transferred to global cities by the TNCs; another part of it is remitted by the migrant workers to their homes in the countryside; and the other part of it is accumulated in industrializing areas, where 
the urban landscape has been developed dramatically.

TNCs need to buy large areas of inexpensive land to build their factories. After leveling the ground, they next secure supplies of electricity, water, sewage disposal, gas and steam, and establish transportation and communication lines. Some corporations may be compelled to build power plants, dig deep wells, and lay long cables or pipelines by themselves. If local governments or communities are able to provide the necessary infrastructure prior to the establishment of factories, TNCs are willing to make direct investment in the region. The corporations then construct factories, storehouses and offices, as well as dormitories and dining halls for their workers. The local governments and communities in the region encourage the corporations not to relocate the factories in order to avoid negative economic influences such as a decrease in employment. Actually, many 'township enterprises' have been set up by TNCs and operated as their branch plants based on the contracts of 'san lai yi bu' (three types of processing and one compensation). The income of processing fees has also been an indispensable benefit for local communities.

Locational conditions which TNCs need for their production are not only abundant labour force but also sufficient land and infrastructure for production and transportation with a certain standard. Every local community in the rural area competitively supplies a large area of land by the conversion of their agricultural land and invests its capital accumulated as community reserve into land development for the purpose of inviting more foreign investment. At the same time, land development promotes the capital accumulation of the local community in rural areas. The local community can obtain a large income from expropriation compensation, joint business based on land use right, and rent (Figure 1). The capital flows through land market also derive from the investment by foreign enterprises in the region. Rural areas are behind urban areas in the progress of land system reform, so it was slow for government to extend its control on land by rent collection or town planning toward the rural area. This situation is also an advanta- geous factor for rural communities to become production bases of foreign enterprises. As a result, a circulation of capital from foreign investment through local capital accumulation to land development has come to existence in rural areas.

A part of community reserve is invested in social overhead capital related to daily life and another part is distributed to village people through share cooperation system and invested in their own housing. While migrant workers from inland areas such as Sichuan and Hunan become indispensable labour force for production in the factories, local peasants tend to become engaged in the commercial, service, and public sectors, and increase their income. Land previously used for agriculture has been quickly transferred to urban use. Not only production facilities but also houses, shops, and other urban facilities have been constructed increasingly. All of these have been promoting the formation of the urban landscape (Onodera 1997).

\section{Concluding Remarks}

This paper has insisted on the necessity to explore the mechanism of the extended urban landscape formation, based on a review of the discussion about desakota phenomenon. In order to understand the mechanism, it is necessary for us to examine capital accumulation that supports concrete urban construction. It focuses on the PRD region as an interesting case of dynamic urban formation. In the process of exploration, a global viewpoint is kept in mind, as the PRD economy has already been incorporated in the international division of labour.

The formation of extended urban landscape has begun since foreign enterprises that have footholds at Hong Kong transferred their labour-intensive production function into the PRD region in the 1980s. Factories have grown in size and have been relocated to the region to make use of the availability of land and the cheaper labour force.

The influx of workers from rural areas has created a new regional labour market in the PRD region. Since young eligible workers are 
(A)

A case where state-owned land is used by foreign enterprise

(1)

Government

(B)

A case where collective-owned land is expropriated by government and used by foreign enterprise

(1) (3)

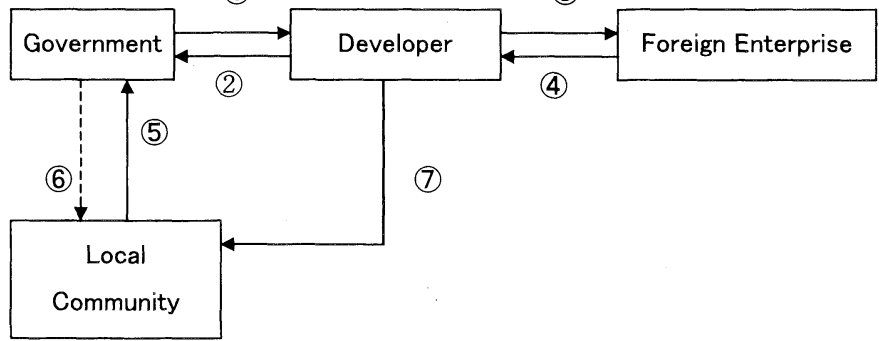

(C)

A case where collective-owned land is used by foreign enterprise without expropriation

(3)

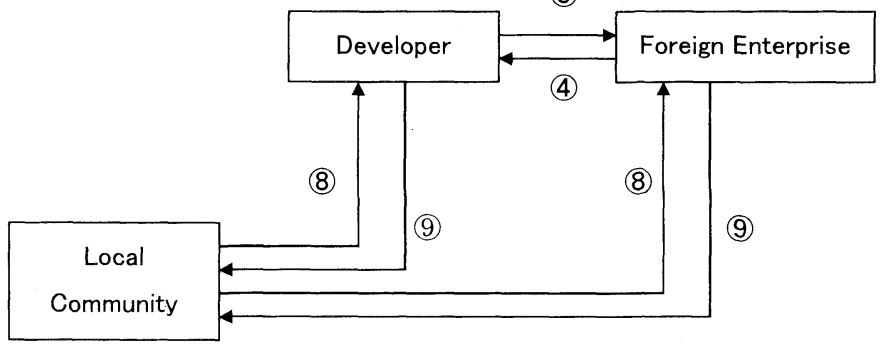

where
(1) Conveyance
(6) Expropriation compensation (formal)
(2) Land value
(7) Expropriation compensation (actual)
(3) Transfer
(8) Investment of land use right to joint business/Lease of land use right
(4) Transfer price
(5) Expropriation
(9) Profit from joint business/Rent

Figure 1. Transfer of land use right and capital flow

Source: Onodera (1997)

Notes:

(1) Expropriation compensation included in (B)-(2) is formally paid through government (6)), but it is actually paid from real estate development enterprise (developer) to local community directly (7)).

(2) In the cases of (A) and (B), some foreign enterprises themselves carry out comprehensive land development as real estate development enterprises.

supplied selectively and continuously with relatively low wages, the segmented regional labour market is maintained, making it easy for TNCs to accumulate their capital. It is also advantageous for migrants to come here because they can easily find good jobs. As a result, both factories and migrant workers have agglomerated in the region.

Land demand in the PRD region has been dependent on the shift of production function of TNCs into the region since the 1980s. The direct investment by foreign enterprises has 
been a driving force of land development there. Such investment has played an important role for the capital accumulation of local governments and communities in the region under the new land system. In rural area, local communities have accumulated land profits from the compensation of land expropriation and rent of collective-owned land, and promoted land development in their domains.

The inter-regional relationship between H.Q. and branch-plants can be regarded as the incorporation of a local economy into the New International Division of Labour (NIDL). Once the NIDL is formed, surplus will be extracted through profit repatriation, royalties, and patent agreements, and through accounting mechanisms within the corporation (Gilbert and Gugler 1992). Armstrong and McGee (1985: 50-51, 57-59) have represented diagrammatically capital and labour flows and accumulation in a hypothetical urban system, which includes labour movements, trade flows and other capital flows such as financial transfers and direct production investment.

However, this study shows a case that local economic players accumulate capital and promote the formation of urban landscape although the regional economy is incorporated in the NIDL. Each local community takes the initiative in accumulating capital and improving its own built-environment, so that extended urban landscape has been formed in the region.

As the urban formation in the region partly depends on external factors, it is likely that the system of capital accumulation will change dramatically. Then the change will lead to another stage of urban landscape transformation in the region. Although the builtenvironment has already been fixed to land and is not altered easily, it will transform gradually but certainly. The signs of a new type of urban formation may appear in the near future.

\section{Acknowledgements}

I am much indebted to Prof. C. K. Leung for encouraging me throughout my stay in Hong Kong. I also wish to express my gratitude to Prof. V. F. S. Sit, Prof. C. Y. Jim, Dr. Y. S. F. Lee, Dr. G. C. S. Lin and Dr. J. J. Wang at the University of Hong Kong for their full support. I would like to thank Prof. T. Taniuchi at the
University of Tokyo for his careful advice on my study.

(Received Aug. 29, 1999)

(Accepted Nov. 1, 1999)

\section{References}

Armstrong, W. and McGee, T. G. 1985. Theatres of Accumulation: Studies in Asian and Latin American Urbanization. London: Methuen.

Chan, R. C. K. 1995. The Pearl River Delta Region. In Development in Southern China: A Report on the Pearl River Delta Region including the Special Economic Zones, eds. J. Cheng and S. Macpherson, 121. Hong Kong: Longman Hong Kong.

Chan, R.C.K. 1996. Regional Development of the Pearl River Delta Region under the Open Policy. In China's Regional Economic Development, eds. R. C. K. Chan, T. T. Hsueh and C. M. Luk, 305-321. Hong Kong: Hong Kong Institute of Asia-Pacific Studies, Chinese University of Hong Kong.

Chen, J. Y. ed. 1988. Xiangzhen qiye moshi yanjiu (Study on Models of Township Enterprises). Beijing: Zhongguo Shehui Kexue Chubanshe. (C)

Druijven, P. C. J. 1993. Trends of Urbanization in the Pearl River Delta. In Urban Problems and Urban Development in China, ed. W. Taubmann, 143-164. Hamburg: Mitteilungen des Instituts fur Asienkunde.

Fei, H. T. et al. 1986. Small Towns in China: Functions, Problems and Prospects. Beijing: New World Press.

Fei, X. T. 1984. Xiaochengzhen, Dawenti (Small Town, Big Issue). In Small Town, Big Issue: Jiangsu Province Small Town Research Anthology, the First Volume, ed. Jiangsu Province Small Town Research Group. Nanjing: Jiangsu Renmin Chubanshe. (C)

Forbes, D. K. 1984. Post-Dependency Theories of Undevelopment. In The Geography of Underdevelopment: A Critical Survey. Sydney: Croom Helm.

Forbes, D. and Thrift, N. eds. 1987. The Socialist Third World: Urban Development and Territorial Planning. Oxford and New York: Basil Blackwell.

Gilbert, A. and Gugler, J. 1992. Cities, Poverty and Development: Urbanization in the Third World (Second Edition). New York: Oxford University Press.

Ginsburg, N. 1990. Extended Metropolitan Regions in Asia: A New Spatial Paradigm. In The Urban Transition: Reflections on the American and Asian Experiences, N. Ginsburg, 19-43. Hong Kong: Chinese University Press.

Ginsburg, N. 1991. Extended Metropolitan Regions in Asia: A New Spatial Paradigm. In The Extended Metropolis: Settlement Transition in Asia, eds. N. Ginsburg, B. Koppel and T. G. McGee, 27-46. Honolulu: University of Hawaii Press.

Guldin, G. E. 1992. An Urbanizing China. In Urbaniz- 
ing China, ed. G. E. Guldin, 223-231. New York: Greenwood Press.

Ishida, H. 1988. Chugoku no noson kogyoka to noson keizai no kadai (Problems of Rural Industrialization and Rural Economy in China). The Economic Review of Kansai University, 38. (J)

Ishikawa, S. 1990. Kaihatsu keizaigaku no kihon mondai (Fundamental Issues of Development Economics). Tokyo: Iwanami Shoten. (J)

Johnson, G. E. 1992. The Political Economy of Chinese Urbanization: Guangdong and the Pearl River Delta Region. In Urbanizing China, ed. G. E. Guldin, 185-220. New York: Greenwood Press.

Johnson, G. E. 1995. Continuity and Transformation in the Pearl River Delta: Hong Kong's Impact on its Hinterland. In The Hong Kong-Guangdong Link: Partnership in Flux, eds. R. Y. W. Kwok and A. Y. So, 64-86. Hong Kong: Hong Kong University Press.

Kirkby, R. J. R. 1988. Urbanization in China: Town and Country in a Developing Economy 1949-2000 AD. London: Routledge.

Leung, C. K. and Chai, J. C. H. 1985. The Economic and Spatial Dimensions of Development in China. In Development and Distribution in China, eds. C. K. Leung and J. C. H. Chai, 3-17. Hong Kong: Centre of Asian Studies, University of Hong Kong.

Li, S. M. 1989. Labour Mobility, Migration and Urbanization in the Pearl River Delta Area. Asian Geographer, 8-1 \& 2: 35-60.

Li, S. M. and Siu, Y. M. 1994. Population Mobility. In Guangdong: Survey of a Province Undergoing Rapid Change, eds. Y. M. Yeung and D. K. Y. Chu, 373400. Hong Kong: Chinese University Press.

Lin, G. C. S. 1997. Red Capitalism in South China: Growth and Development of the Pearl River Delta. Vancouver: UBC Press.

Lo, C. P. 1989. Population Change and Urban Development in the Pearl River Delta: Spatial Policy Implications. Asian Geographer, 8-1 \& 2: 11-34.

Ma, L. J. C.and Fan, M. 1994. Urbanization from Below: The Growth of Towns in Jiangsu, China. Urban Studies, 31: 1625-1645.

Ma, A. Z. and Hu, B. L. 1993. Chengxiang lianxi: Lilun chanshi yu moshi xuanze (Urban-rural Relationship: Theoretical Explanation and Model Selection). Zhongguo Nongcun Jingii (China's Rural Economy), 8: 51-55. (C)

Marton, A. M. 1994. Quyu jingji fazhan he chengxiang guanxi: Yazhou fazhanzhong diqu kongjian jingji zhuanbian de xin lilun kuangjia (Regional Economic Development and RuralUrban Relations: New Theoretical Framework on Spatial Economic Change in Asian Developing Area). Jingji Dili (Economic Geography), 14-1: 11-15. (C)

Maruya, T. 1992. Economic Relations between Hong Kong and Guangdong Province. In Guangdong: 'Open' Door Economic Development Strategy, ed. T.
Maruya, 126-146. Centre of Asian Studies Occasional Papers and Monographs, 105. Hong Kong: Centre of Asian Studies, University of Hong Kong.

McGee, T. G. 1989. Urbanisasi or Kotadesasi?: Evolving Patterns of Urbanization in Asia. In Urbanization in Asia: Spatial Dimensions and Policy Issues, eds. F. J. Costa, A. K. Dutt, L. J. C. Ma and A. G. Noble, 93-108. Honolulu: University of Hawaii Press.

McGee, T.G. 1991. The Emergence of Desakota Region in Asia: Expanding a Hypothesis. In The Extended Metropolis: Settlement Transition in Asia, eds. N. Ginsburg, B. Koppel and T. G. McGee, 3-25. Honolulu: University of Hawaii Press.

McGee, T. G. and Yeung, Y. M. 1993. Urban Futures for Pacific Asia: Towards the 21st Century. In Pacific Asia in the 21st Century: Geographical and Developmental Perspective, ed. Y. M. Yeung, 69103. Hong Kong: Chinese University Press. Xueshu Shukan Chubanshe. (C)

Onodera, J. 1991. Chugoku noson kogyo no sonritsu kozo no henka: Nankin-shi Konei-ken wo jirei toshite (Industrial Restructuring in Rural China: A Case Study in Jiangning County, Nanjing). Annals of the Japan Association of Economic Geographers, 45-1: 383-406. (JE)

Onodera, J. 1997. Chugoku ni okeru tochi seido kaikaku to toshi keisei: Shuko deruta chiiki, Shinsen-shi no jirei kara (Land System Reform and Urban Formation in China: A Case Study in Shenzhen Municipality, Pearl River Delta Region). Ajia Keizai (Asian Economy), 38-6: 2643. ( $\mathrm{J})$

Onodera, J. 1998. Industrial Restructuring in Hong Kong and Its Extension to the Pearl River Delta Region, China. Science Reports, Tohoku. Univ., 7th Ser. (Geogr.), 48: 1-34.

Onodera, J. and Oshima, K. 1996. Kanton-sho ni okeru rodoryoku ryudo no yoin bunseki: Ken reberu no tokei shiryo wo chushin ni (Labour Migration in Guangdong Province: Factor Analysis Based on County Level Statistics). Chugoku Kenkyu Geppo (Monthly Bulletin of Chinese Studies), 575: 1-14. (J)

Oshima, K. 1987. Chugoku noson keizai ni okeru gochin kigyo no yakuwari ni kansuru ichi kosatsu: Koso-sho Mushaku-ken H-go no jirei wo chushin ni (A Study on the Role of Township and Village Enterprises in China's Rural Economy: A Case of H Township in Wuxi County, Jiangsu Province). Noson Kenkyu (Rural Studies), 64. (J)

Oshima, K. 1996. Chugoku no dekasegi rodosha: Noson rodoryoku ryudo no genjo to yukue (Migrant Workers in China: Present Condition and Future of Rural Labour Migration). Tokyo: Ashi Shobo. (J)

Pannell, C. W. and Veeck, G. 1989. Zhujiang Delta and Sunan: A Comparative Analysis of Regional 
Urban Systems and their Development. Asian Geographer, 8-1 \& 2: 133-149.

Shi, Y.L. 1998. Desakota moshi ji qi dui woguo chengxiang jingji zuzhi fangshi de qishi (Desakota Model and Its Enlightenment to the Organization of Urban-Rural Economy in Our Country). Guotu yu Quyu Jingji (Spatial Planning and Regional Economy), bound volume of 1 to 4 : 124-129. (C)

Sit, V.F.S. 1991. Transnational Capital Flows and Urbanization in Pearl River Delta, China. Southeast Asian Journal of Social Science, 19-1 \& 2: 154-179.

Sit, V.F. S. 1993. Transnational Capital Flows, Foreign Investments, and Urban Growth in Developing Countries. In Third World Cities: Problems, Policies, and Prospects. eds. John D. Kasarda and Alan M. Parnell, 180-198. Newbury Park, California: Sage Publications.

Sit, V. F. S. 1995. Industrial Transformation of Hong Kong. In The Hong Kong-Guangdong Link: Partnership in Flux. eds. R. Y. W. Kwok and A. Y. So, 163-186. Hong Kong: Hong Kong University Press.

Sit, V.F.S. and Yang, C. 1997. Foreign-investmentinduced Exo-Urbanization in the Pearl River Delta, China. Urban Studies, 34: 647-677.

Soulard, F. 1993. 'The Restructuring of Hong Kong Industries and the Urbanization of Zhujiang Delta, 1979-1989'. Diss. Chinese University of Hong Kong.

Tan, K. C. 1989. Small Town Development and the Environment: Hope and Reality. In Resources, Environment and Regional Development. eds. C. K. Leung, C. Y. Jim and D. K. Zuo, 332-352. Hong Kong: Centre of Asian Studies, University of Hong Kong.

Tsurumi, K. and Kawata, T. eds. 1989. Naihatsuteki hatten ron (Study on Endogenous Development). Tokyo: Tokyo University Press. (J)

Uno, S. 1989. Chugoku ni okeru gochin kigyo to shojochin kensetsu mondai: Koso-sho wo chushin tosite (Problems of Township and Village Enterprises and Small Cities and Towns' Construction in China: Case of Jiangsu Province). In Chiiki kenkyu to daisan sekai (Regional Studies and the Third World), ed. Regional Research Centre, Keio University, 3-29. Tokyo: Keio Tsushin. (J)

Uno, S. and Tsurumi, K. eds. 1994. Naihatsuteki hatten to gaikogata hatten: Gendai Chugoku ni okeru kosaku (Endogenous Development and Extravert Development: Intersection in Modern China). Tokyo: Tokyo University Press. (J)

Uno, S. and Zhu, T. H. eds. 1991. Noson chiiki no kindaika to naihatsuteki hatten ron: Nitchu 'shojochin' kenkyu (Modernization of Rural Area and Study on Endogenous Development: Japanese-Chinese Joint Research on 'Small Township'). Tokyo: Kokusai Shoin. (J)
Wei, Q. Q. 1999. Zhujiang Sanjiaozhou chengxiang yitihua tantao (The Integration between Urban and Rural Areas in the Pearl River Delta). In Yiguo liangzhi moshi de quyu yitihua yanjiu (Studies on the Regional Integration under the Model of 'One Country Two Systems'), eds. S. Z. Ye, C. L. Gu and A.F. Niu, 147-151. Kexue Chubanshe. (C)

Woo, E. S. W. 1994. Urban Development. In Guangdong: Survey of a Province Undergoing Rapid Change, eds. Yeung, Y. M. and D. K. Y. Chu, 327354. Hong Kong: Chinese University Press.

Wu, Z. T., Xu, X. Q. and Liang, Z.Q. 1987. Introduction. In Development of China's Small Cities, eds. X. Q. Xu, Z.T. $\mathrm{Wu}$ and Z.Q. Liang, 1-13. Guangzhou: Zhongshan Daxue Chubanshe. (C)

Xu, X. Q. 1988. Zhujiang sanjiaozhou shizhen fazhan kongjian moshi de zhuanhua (Spatial Change of Urban Development in PRD). In Zhujiang Sanjiaozhou de fazhan yu chengshihua (Development and Urbanization in the Pearl River Delta Region), eds X. Q. Xu, Q. Liu and X. Z. Zeng, 322346. Guangzhou: Zhongshan Daxue Chubanshe. (C)

Xu, X. Q. 1998. Daoyan: Zhongguo xiangcun-chengshi zhuanxing de dongli he leixing (Introduction: Driving Force and Patterns of Rural-Urban Transformation in China). In Zhongguo xiangcunchengshi zhuanxing yu xietiao fazhan (Rural-Urban Transformation and Cooperative Development in China), eds. X. Q. Xu, F. X. Xue and X. P. Yan, iiivii. Kexue Chubanshe. (C)

Xu, X.Q. and Hu, H. Y. 1988. Duiwai kaifang dui Zhujiang Sanjiaozhou shizhen fazhan de yingxiang (Influence of Open Policy on Urban Development in the Pearl River Delta Region). In Zhujiang Sanjiaozhou chengshi huanjing yu chengshi fazhan (Urban Environment and Urban Development in the Pearl River Delta Region), 166-180. Guangzhou: Zhongshan Daxue Chubanshe. (C)

Xu, X. Q., Kwok, R. Y. W., Li, L. X. and Yan, X. P. 1995 Production Change in Guangdong. In The Hong Kong-Guangdong Link: Partnership in Flux. eds. R. Y. W. Kwok and A. Y. So., 135-162. Hong Kong: Hong Kong University Press.

Xu, X. Q. and Li, S. M. 1990. China's Open Door Policy and Urbanization in the Pearl River Delta Region. International Journal of Urban and Regional Research, 14-1: 50-68.

Xu, X.Q., Liu, Qi and Zeng, X.Z. 1988. Zhujiang Sanjiaozhou de fazhan yu chengshihua (Development and Urbanization in the Pearl River Delta Region). Guangzhou: Zhongshan Daxue Chubanshe. (C)

Xue, D. S., Chen, W. J. and Hou, Q. Z. 1998. Youguan 'xiangcun chengshihua' he 'chengxiang yitihua' deng jige gainian de bianxi (Distinction among Several ideas concerning 'Rural Urbanization' 
and 'Urban-Rural Integration'). Chengshi Wenti (Urban Problems), 81: 14-16. (C)

Xue, F. X. and Yang, C. 1997. Waizi: Fazhanzhong guojia chengshihua de xindongli: Zhujiang Sanjiaozhou gean yanjiu (Foreign Investment: New Motive Force of Urbanization in a Developing Country: A Case Study in the Pearl River Delta). Dili Xuebao (Acta Geographica Sinica), 52: 193-206. (C)

Yamauchi, K. 1988. Gendai Chugoku no keizai kaikaku (Economic Reform of Modern China). Tokyo: Gakuyo Shobo. (J)

Yan, X. P., Lin, C. S. and Xu, X. Q. 1994. Dili, diqu, chengshi: Yongwuzhijing de tansuo (Geography, Region and City: Never-ending Exploration). Guangzhou: Guangdong Gaodeng Jiaoyu Chubanshe. (C)

Yao, S. M. 1991. Chengshiqun shengzhang yinsu tansuo (Exploration of Growth Factors of Urban Agglomerations). Chengshi Yanjiu (Urban Studies). (C)

Yao, S. M., Xu, X. Q., Wu, C. C., Huang, G. Y., Wang, L. P., Sun, J. S., Liu, D. H., Zhang, Z. S., Luo, D. B., Zhang, Y. G., Liu, T., Shuai, J. P., Yu, B. Y., and Hou, X. H. 1992. Zhongguo de chengshiqun (The Urban Agglomerations of China). Hefei: Zhongguo Kexue Jishu Daxue Chubanshe. (C)
Zheng, T. X. 1989. Gang Ao yu Zhujiang Sanjiaozhou kongjian guanxi moshi. (The Spatial Relationships among Hong Kong, Macao and the Pearl River Delta Area). In Zhujiang Sanjiaozhou huanjing yu kongjian fazhan (The Environment and Space Development in the Pearl River Delta), eds. X. Q. Xu, J. Ye and C. E. Wen, 253-262. Beijing: Xueshu Shukan Chubanshe. (C)

Zheng, T.X. and Wu, J.W. 1993. Zhujiang Sanjiaozhou tongxiang 21 shiji chengshihua celüe (The Tactics of Urbanization toward 21 Century in the Pearl River Delta Region). Zhujiang Sanjiaozhou Jingii (Pearl River Delta Economy), 3: 5-17. (C)

Zhou, D. M. 1996. Zhongguo de xiangcun dushihua (China's Rural Urbanization). In Zhongguo xiangcun dushihua (China's Rural Urbanization), ed. Q. E. Pan, 17-56. Guangzhou: Guangdong Renmin Chubanshe. (C)

Zhou, Y.X. 1991. The Metropolitan Interlocking Region in China: A Preliminary Hypothesis. In The Extended Metropolis: Settlement Transition in Asia, eds. N. Ginsburg, B. Koppel and T. G. McGee, 89-112. Honolulu: University of Hawaii Press.

Zhou, Y.X. 1993. 'Desakota' yici de youlai he hanyi (Origin and Meaning of 'Desakota'). Chengshi Wenti (Urban Problems), 5: 13. (C) 